\title{
Short Communication: \\ Update phylogenetic information of the local varieties of cloves (Syzygium aromaticum) from North Maluku, Indonesia based on ITS sequences data
}

\author{
SUNDARI I,2,v, NURHASANAH ${ }^{1, v v}$, ABDU MAS'UD ${ }^{1, v v v}$, MOHAMAD AMIN ${ }^{3, v v v ",}$

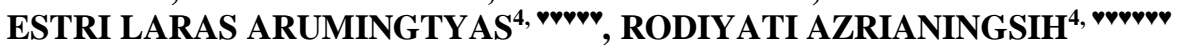 \\ ${ }^{1}$ Department of Biology Education, Faculty of Teacher Training and Education, Universitas Khairun. Jl. Pertamina Kampus II Unkhair Gambesi, Ternate \\ 97728, North Maluku, Indonesia. Tel.: +62-921-3110901, Fax.: +62-921-3110903, "email: sundari@unkhair.ac.id; "vnurhasanah@unkhair.ac.id; \\ ${ }^{2}$ Biotechnology Laboratory, Universitas Khairun. Jl. Pertamina Kampus II Unkhair Gambesi, Ternate 97728, North Maluku, Indonesia \\ ${ }^{3}$ Faculty of Mathematics and Natural Sciences, Universitas Negeri Malang. J1. Semarang No. 5, Sumbersari, Malang City 65145, East Java, Indonesia.

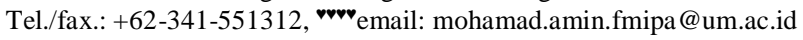 \\ ${ }^{4}$ Faculty of Mathematics and Natural Sciences, Universitas Brawijaya. Jl. Veteran 5, Sumbersari, Lowokwaru, Malang City 65145, East Java, Indonesia.

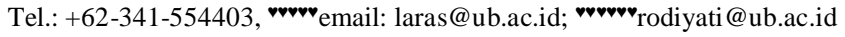

Manuscript received: 23 August 2018. Revision accepted: 3 April 2019.

\begin{abstract}
Sundari, Nurhasanah, Mas'ud A, Amin M, Arumingtyas EL, Azrianingsih R. 2019. Update phylogenetic information of the local varieties of cloves (Syzygium aromaticum) from North Maluku, Indonesia based on ITS sequences data. Biodiversitas 20: 15101515. Clove (Syzygium aromaticum L. Merr \& Perry) is a native spice plant species in Indonesia, especially Maluku and North Maluku. The phylogenetic relationship among local varieties of cloves in North Maluku, Indonesia is currently unclear; therefore molecular verification research is required for further conservation and breeding programs. This study aims to identify the taxonomic position and phylogenetic relationship among two valuable local varieties of cloves from North Maluku, i.e., 'Afo' and 'Sibela', based on ITS sequences data. Afo clove is considered as the oldest clove native to Ternate island, and Sibela clove is the oldest clove native to Bacan Island. The phylogenetic analysis using both Maximum Parsimony and Neighbour Joining algorithms confirmed the monophyletic group of cloves (S. aromaticum) and separated to outgroup of Eugenia species. Both phylogenetic trees produced three clades with the same pattern and supported by strong bootstrap values of $99-100 \%$.
\end{abstract}

Keywords: Ancestor, clove, ITS, native, North Maluku, phylogenetic

\section{INTRODUCTION}

Clove (Syzygium aromaticum L. Merril \& Perry) is aromatic flower buds of a tree species in the family Myrtaceae, indigenous to the Maluku Islands (the Moluccas) in Indonesia, and are commonly used as spice. During the Dutch colonialism, clove cultivation had spread to many islands and countries to Malaysia, Sri Lanka, Tanzania, Madagascar, and recently also Brazil (Verheij and Snijders 1999; The Crop State Statistics of Indonesia 2015). There are many local varieties of cloves recorded in Indonesia. The classification of cloves in Indonesia based on 35 morphological characters was categorized into three groups, i.e., cultivated cloves, local cloves from Maluku and wild cloves (Pool et al. 1986; The Crop State Statistics of Indonesia 2015).

In particular, North Maluku is known as Spice Island (Amal 2010) and one of the center of clove production in the world (Purseglove et al. 1981; Tresniawati and Eny 2011). The geographical distribution of cloves in the North Maluku Islands ranges from Ternate, Tidore, Moti, Makian, and Bacan (Purseglove et al. 1981). Some of the local cloves from North Maluku which have been recorded include Afo 1, Afo 2, Tibobo, Tauro, Sibela, Indari, Dokiri, and Leaf Buntal. Further, Sibela and Indari cloves were considered as wild clove types (Nurdjannah and Bermawie 2012; Pool et al. 1986).

Currently, there is no information about the taxonomical position and phylogenetic relationship among the local varieties of cloves in North Maluku. Thus, research to verify them using molecular approaches are required to conduct. Historically, the Afo clove was reported as the oldest clove native to Ternate island, and Sibela clove is the oldest clove native to Bacan island (Amal 2010). Those two local varieties are considered as valuable genetic resources of cloves in North Maluku. Clearer information of the taxonomical position and phylogenetic relationship of those two local varieties of clove can be used as an important reference for further conservation and breeding programs of clove in Indonesia.

This study aims to identify the taxonomical position of the valuable local varieties of cloves, i.e., Afo and Sibela from North Maluku, and reveal their phylogenetic relationship based on Internal Transcribed Spacer (ITS) sequences data. The ITS region is a non-coding region located in the nuclear genome of ribosomal DNA (rDNA). It has mild functional problems; therefore its evolution occurred more neutrally and naturally (Álvarez and Wendel 
2003). It is also easy to be amplified using universal primers, has high sensitivity due to its small size (300-800 bp) and high copy number in the genome (100-200 copies) (Baldwin et al. 1995). It has been proven to be a useful source of informative characters for genetic variability and phylogenetic studies in many Angiosperm families (Baldwin et al. 1995; Yonemori et al. 2002; Biffin et al. 2007; Fitmawati 2016; Wilson and Heslewood 2016; Hapsari et al. 2018). Hence, it was expected that the use of ITS gene sequences will produce the best phylogenetic tree model which are useful for further conservation and breeding programs of native cloves in Indonesia.

\section{MATERIALS AND METHODS}

\section{Study area}

The sampling of clove plants was carried out on two islands, i.e., Ternate (Afo clove spot) and Bacan island (Sibela clove spot) (Figure 1). Ternate Island is located in a geographical position: $0^{\circ} \mathrm{NL}-2^{\circ} \mathrm{NL}$ and $126^{\circ} \mathrm{EL}-128^{\circ} \mathrm{EL}$. The climate in Ternate Island has a relatively high air temperature, with averaged air temperature $27^{\circ} \mathrm{C}$ (max. $31^{\circ} \mathrm{C}$ and min. $20^{\circ} \mathrm{C}$. The highest rainfall month in July, with 23 rainy days and precipitation up to $478 \mathrm{~mm}$. Meanwhile, Bacan Island is located in South Halmahera district at a geographical position of $0^{\circ} 30^{\prime} \mathrm{NL}-2^{\circ} 00^{\prime} \mathrm{SL}$ and $126^{\circ} 45^{\prime} \mathrm{EL}-129^{\circ} 30^{\prime} \mathrm{EL}$. The air temperature is relatively high, with averaged $23.6^{\circ} \mathrm{C}\left(\max .31 .8^{\circ} \mathrm{C}\right.$ and $\min .26^{\circ} \mathrm{C}$ ). The highest rainfall month is in May, with 24 rainy days and precipitation up to $212.3 \mathrm{~mm}$.

\section{Plant materials}

Plant materials used in this study were four samples from two local varieties of cloves originated from North Maluku, i.e., Afo clove from Ternate Island, and Sibela clove from Bacan Island. Two samples from the different tree were taken for each variety (Figure 2, Table 1). Those local clove varieties from North Maluku were compared to Syzygium aromaticum from Genbank (NCBI) (Ray 2015), and their closely related species Eugenia greggii and Eugenia bunchosiifolia as out-groups from Genbank (NCBI) (Van Der Merwe et al. 2005; De Oliveira et al. 2016) (Table 1).

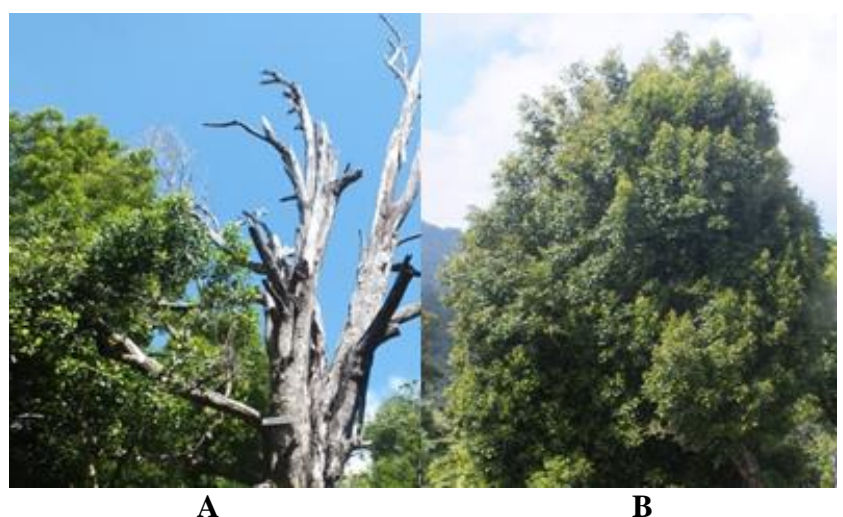

Figure 2. The clove plant habitus of North Maluku, Indonesia: A. Afo clove in Ternate island; B. Sibela clove in Bacan island
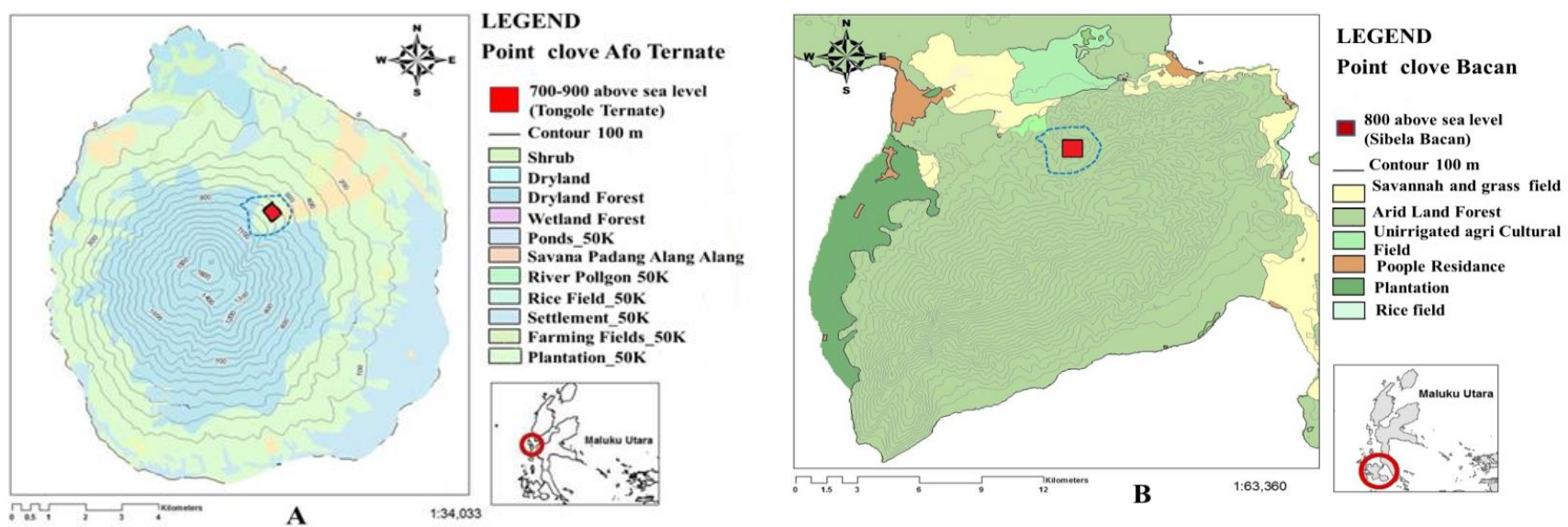

Figure 1. The map of sampling location in North Maluku, Indonesia: A. Ternate Island (Afo clove spot); B. Bacan Island (Sibela clove spot)

Table 1. List of North Maluku, Indonesia clove samples analyzed, and accession numbers of cloves and close related species from GenBank (NCBI)

\begin{tabular}{llcl}
\hline Species name and code & Locality & Genbank accession number & Notes \\
\hline Syzygium aromaticum Afo 1 & Ternate Island, Indonesia & This study & In-group \\
Syzygium aromaticum Afo 2 & Ternate Island, Indonesia & This study & In-group \\
Syzygium aromaticum Sibela 2 & Bacan Island, Indonesia & This study & In-group \\
Syzygium aromaticum Sibela 1 & Bacan Island, Indonesia & This study & In-group \\
Syzygium aromaticum & India & KT982668 & In-group \\
Eugenia greggii & South Africa & KY487285 & Out-group \\
Eugenia bunchosiifolia & Brazil & KX789268 & Out-group \\
\hline
\end{tabular}




\section{DNA isolation, Polymerase Chain Reaction (PCR) and sequencing procedures}

Total DNA was isolated from $100 \mathrm{mg}$ of young leaves. DNA isolation procedure was performed according to the manual instructions supplied by Geneid DNA miniprep kit (Brand-country). This kit uses a column purification technique which is capable to extract the total plant DNA. Plant cells were lysed using lysis buffer, and proteinase K. Protein and waste material were separated by centrifugation at $13.000 \mathrm{rpm}$ for $5 \mathrm{~min}$. The supernatant was passed through a silica membrane column. The total DNA was then washed from residual protein and salt by eluted in Eppendorf tube $1.5 \mathrm{ml}$ and incubated at $-20^{\circ} \mathrm{C}$ for 8 hours.

DNA amplification was prepared by using PCR Master Mix (Intron-company) in $40 \mu \mathrm{L}$ of a total volume containing 1.25 units Taq DNA polymerase, $0.2 \mathrm{mM}$ dNTP mix, $1.5 \mathrm{mM} \mathrm{MgCl}_{2} ; 0.2 \mathrm{mM}$ of each primer and $0.6 \mu \mathrm{g}$ DNA sample. The ITS primer pairs used in this study were ITS-L (5' TCG TAA CGT TTC CAA GGT AGG TG 3') as the forward primer and ITS -4 (5, TCC TCC GCT TAT TGA TAT GC 3') as a reverse primer (White et al. 1990). The PCR reaction was done under a condition as follow: initial denaturation at $95^{\circ} \mathrm{C}$ for 5 minutes then continued 35 cycles of denaturation at $95^{\circ} \mathrm{C}$ for 45 seconds; annealing at $54.5^{\circ} \mathrm{C}$ for 45 seconds, extension at $72^{\circ} \mathrm{C}$ for 45 seconds and a final extension at $72^{\circ} \mathrm{C}$ for 7 minutes. The PCR products were then confirmed by electrophoresis with $1.5 \%$ agarose gel with $\mathrm{EtBr}$ and visualized via UVtransilluminator. The amplified PCR products were purified and sent for sequencing to First Base Sequencing Laboratory (Malaysia) using ABI PRISM ${ }^{\circledR} 310$ Genetic Analyzer.

\section{Data analysis}

The ITS sequences data were evaluated using sequences scanner v.10. Potential contamination and effectiveness of identification were identified using the Basic Local Alignment Search Tool (BLASTn) program in GenBank (Altschul et al. 1990). Sequences were aligned using ClustalW in the MEGA 5.03 package (Larkin et al. 2007). Sequences were also analyzed using DnaSP 5.10 (Librado et al. 2009) for identifying the insertion-deletion sites, gap sites, polymorphic sites, and conserved sites. The phylogenetic trees were constructed using Maximum Parsimony (MP), and Neighbor-Joining (NJ) algorithms in MEGA 5.03 (Saitou and Nei 1987), with bootstrap 1000 replicates (Felsenstein 1985). Further, the substitution model with the lowest Bayesian Information Criterion (BIC) scores (Nei and Kumar 2000) and Kimura-2Parameter model (Saitou and Nei 1987) were used in this study. Genetic distances analysis (interspecies and intraspecies) was calculated using the Kimura-2-parameter (K2P) model in MEGA 5.03 (Kimura 1980) with bootstrap 1000 replicate (Felsenstein 1985). All positions containing gaps and missing data were eliminated.

\section{RESULTS AND DISCUSSION}

\section{ITS region amplification and DNA sequence characteristic}

Amplification of the ITS region using ITSL and ITS4 primers were successfully carried out on the four clove samples examined from North Maluku. Visualization on $1.5 \%$ agarose gel electrophoresis was shown by the presence of a specific DNA band in the sample lane at the length of approximately $600 \mathrm{bp}$ (Figure 3). DNA sequences length of ITS region in Angiosperms were varied between $400 \mathrm{bp}$ to 800 bp (Baldwin et al. 1995).

Sequencing on ITS region amplicons of four clove samples in this study produced DNA sequences with sizes of $685 \mathrm{bp}$. The ITS sequence size of clove samples was in accordance with the ITS sequence size of clove from GenBank, and also closely related species from Eugenia genus ranged from 609 bp to 721 bp (Van Der Merwe et al. 2005; Ray 2015; De Oliveira et al. 2016). Based on BLASTn on NCBI, all data DNA sequences of four clove samples were homologs with ITS region in Myrtaceae Family with similarity $>95 \%$. There was no contaminant of endophytic fungi. Hence, all those ITS sequences of four clove samples were effective for further genetic variability analysis and phylogenetic reconstruction.

\section{Genetic variability of ITS sequences among local varieties of cloves}

The total aligned and selected ITS region DNA sequences length of ingroup and outgroup was $585 \mathrm{bp}$ positions. Of those, 230 positions (41\%) were identified as conserved region (invariable/monomorphic), 318 positions (56\%) were potential variable sites (polymorphic) and 17 positions $(3 \%)$ were alignment gaps or missing data. About 307 positions $(54 \%)$ of the variable positions were potentially parsimony informative, and 11 positions (19\%) were singleton variables. The ITS region DNA sequences of four local clove samples showed high variability with enough conservation level, so that become valuable characters to reconstruct genetic relationships.

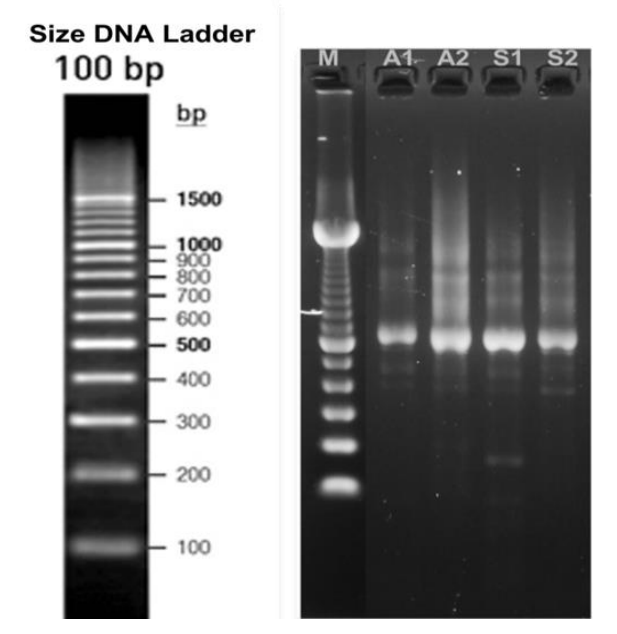

Figure 3. The amplification of ITS gene in 4 samples of native clove from North Maluku. Notes: M: marker; A1: Afo sample 1; A2: Afo sample 2; S1: Sibela sample 1; S2: Sibela sample 2 
Further, the nucleotide composition of ITS region in four clove samples showed high in $\mathrm{G}+\mathrm{C}$ bases content with an average of $62.79 \%$. ITS region as non-coding region or intron was known to have high $\mathrm{G}+\mathrm{C}$ content because it was associated with their related functions in transcription and translation. DNA sequences with higher $\mathrm{G}+\mathrm{C}$ content are hotspots of mutation, $\mathrm{C}$ base is often methylated and occurred errors during multiplication (Hapsari et al. 2018).

\section{Phylogenetic relationship among local varieties of cloves based on ITS sequences}

Genetic relationship analysis of local varieties of cloves based on ITS sequences using Maximum parsimony (MP) and Neighbour-Joining (NJ) algorithms resulted in trees which confirmed the monophyletic group of cloves $(S$. aromaticum) and separated to Eugenia species. Both phylogenetic trees produced three clades with the same pattern, and supported by strong bootstrap values of 99 -
$100 \%$. The clade 1 consists of Eugenia greggii and Eugenia bunchosiifolia, while Clade 2 consists of cloves from India (NCBI) and local variety Afo 1 from Ternate. Interestingly, clove Afo 2 was positioned on Clade 3 separated with Afo 1, and become sister with cloves Sibela 1 and Sibela 2 from Bacan Island (Figure 4; Figure 5).

Pairwise distance analysis using Kimura-2 parameter model (Kimura 1980) showed that they were shared high similarity genetic material of ITS with a low genetic distance of 0.008 to 0.357 among ingroup and outgroup, while within ingroup were 0,051 to 0.343 (Table 2). Genetic distance is used to measure the differences in the genetic structure between two populations/species at a particular gene locus. The minimum value of 0 occurs if genetic structure of two populations/ species are identical, while the maximum value of 1 indicates that they do not share any genetic type (Finkeldey 2005).
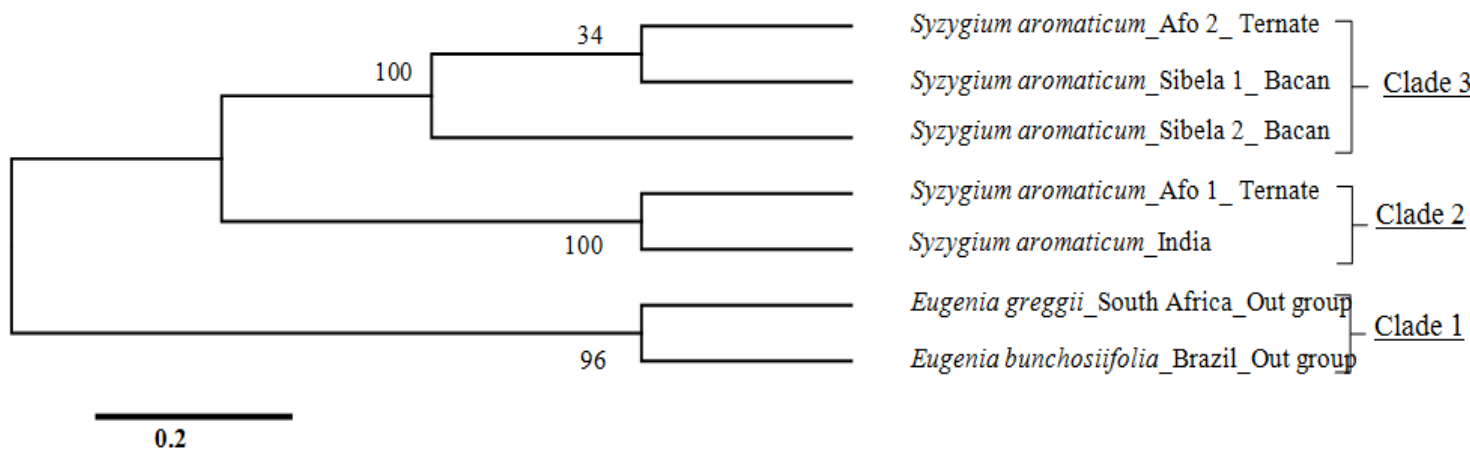

Figure 4. Maximum Parsimony (MP) phylogenetic tree of the local varieties of cloves from North Maluku based on ITS sequences. The values on the branch represent bootstrap and posterior probability value based on 1000 replicate

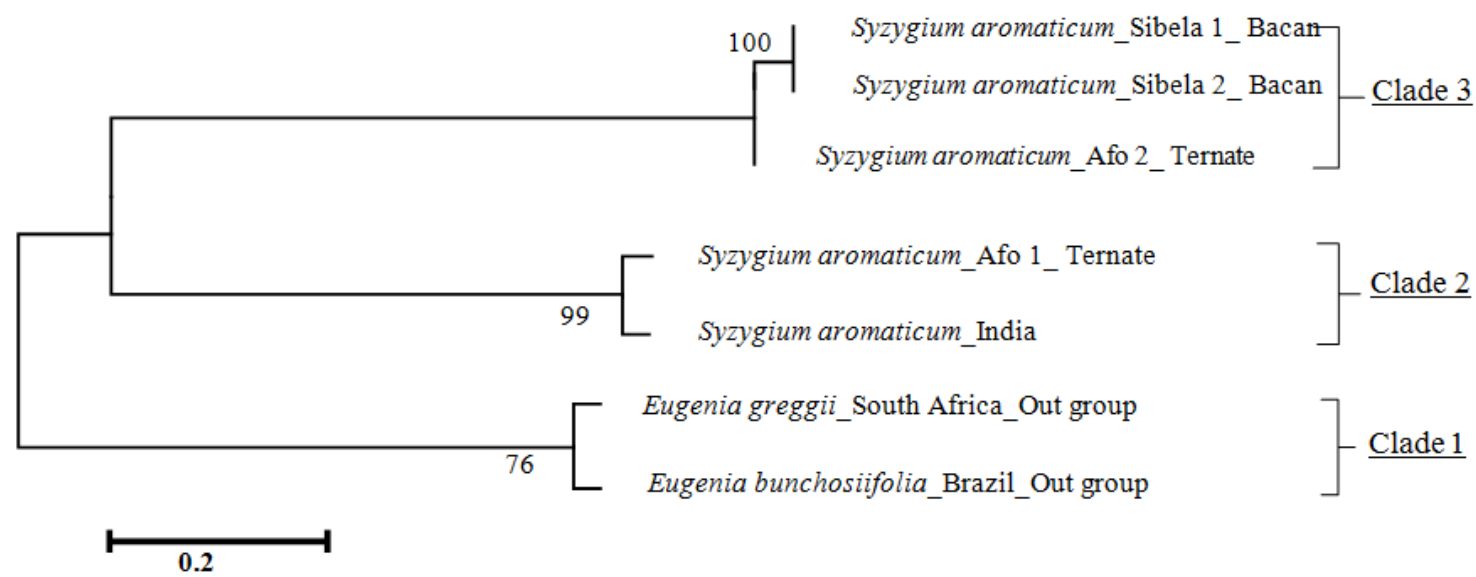

Figure 5.Neighbor-Joining (NJ) phylogenetic tree of local varieties of cloves from North Maluku based on ITS sequences. The values on the branch represent bootstrap and posterior probability value based on 1000 replicate 
Table 2. Matrix pairwise genetic distance based on ITS sequences analyzed by the Kimura-2 parameter model.

\begin{tabular}{lcccccc}
\hline Species name and code & $\mathbf{1}$ & $\mathbf{2}$ & $\mathbf{3}$ & $\mathbf{4}$ & $\mathbf{5}$ & $\mathbf{6}$ \\
\hline Syzygium aromaticum_Afo 2_Ternate & 0.000 & & & & & \\
Syzygium aromaticum_Afo 1_Ternate & 0.357 & 0.000 & & & & \\
Syzygium aromaticum_Sibela 2_Bacan & 0.310 & 0.008 & 0.000 & & & \\
Syzygium aromaticum_Sibela 1_Bacan & 0.310 & 0.008 & 0.000 & 0.000 & \\
Syzygium aromaticum_India & 0.000 & 0.357 & 0.310 & 0.310 & 0.000 & \\
Eugenia greggii_South Africa_Out group & 0.110 & 0.343 & 0.297 & 0.297 & 0.110 & 0.000 \\
Eugenia bunchosiifolia_Brazil_Out group & 0.111 & 0.252 & 0.215 & 0.215 & 0.111 & 0.051 \\
\hline
\end{tabular}

\section{Discussion}

In this study, phylogenetic tree consisted of three main clusters was formed with Eugenia as outgroup. The phylogenetic tree showed the relationship between species and described the changes that occur in the marker genes for each species. The longer a branch means the more changes that occur in the gene marker during the evolutionary process, consequently the species on the branch can be said to be more advanced (Swofford 2000; Sohrab et al. 2014). Based on the analysis of phylogenetic tree is known that Afo 1 clove from Ternate is the ancestor of native clove in North Maluku. Furthermore, Afo 2 clove from Ternate, Sibela 1 clove and Sibela 2 clove from Bacan island are close relatives in one cluster. Afo 2 clove from Ternate, Sibela 1 clove and Sibela 2 clove from Bacan island is the youngest and most modern cluster, because have a longer branch in phylogenetic tree in this study.

The phylogenetic tree indicated that all individuals from local varieties of clove originated from the North Maluku formed monophyletic groups means to have one ancestor. The phylogenetic tree in this study consisted of three clades. Each clade describes the process of speciation during evolution; in this case, the afo 1 clove in clade 2 has the most primitive speciation process. Clade 3 shows the most advanced speciation process. As explained in Ochieng et al. (2007) and Swofford (2000), the phylogenetic tree consists of nodes and branches; each node describes the speciation process during evolution. The length of each branch represents the number of changes that occur in character used before the next separation occurs. The characters with more similar will be close to each other in the intersection (Lestari 2017; Sohrab et al. 2014). The results of phylogenetic analysis in this paper can be used as information in biosystematic study and taxonomy of native clove in North Maluku. This research is a preliminary study for further research in breeding programs and conservation strategies of clove and other spices in North Maluku.

In conclusion, phylogenetic analysis of clove from North Maluku based on the ITS sequence gene provided information there is a genetic relationship between Afo cloves from Ternate island and Sibela cloves from Bacan island. Afo 1 clove is the ancestor of cloves in North Maluku.

\section{ACKNOWLEDGEMENTS}

The authors thank Didik Wahyudi and Lia Hapsari, for his assistance in bioinformatics and molecular data analysis so that the writing of this article can be done.

\section{REFERENCES}

Altschul SF, Gish W, Miller W, Myers EW, Lipman DJ. 1990. Basic local alignment search tool. J Mol Biol 215 (3): 403-410.

Álvarez I, Wendel JF. 2003. Ribosomal ITS sequences and plant phylogenetic inference. Mol Phylogenet Evol 29 (3): 417-434.

Amal MA. 2010. Spice Islands: Historical Journey of Northern Maluku. The popular library of Gramedia, Jakarta. [Indonesia]

Baldwin BG, Sanderson MJ, Porter JM, Wojciechowski MF, Campbell CS, Donoghue MJ. 1995. The ITS region of nuclear ribosomal DNA: a valuable source of evidence on angiosperm phylogeny. Ann Mo Bot Gard: 247-277.

Biffin E, Harrington MG, Crisp MD, Craven LA, Gadek PA. 2007. Structural partitioning, paired-sites models and evolution of the ITS transcript in Syzygium and Myrtaceae. Mol Phyl Evol 43: 124-139.

de Oliveira BM, Fernanda MF, Forest F, Leandro BM, Renato SJ, Lucas EJ. 2016. The evolutionary history of Eugenia sect. Phyllocalyx (Myrtaceae) corroborates historically stable areas in the southern Atlantic forests. Ann Bot 118 (7): 1209-1223.

Felsenstein J. 1985. Confidence limits on phylogenies: an approach using the bootstrap. Evolution 39 (4): 783-791.

Finkeldey R. 2005. An Introduction To Tropical Forest Genetics: Molekuler Basic The Gene As A Function Unit. Institute of Forest Genetics And Forest Tree Breeding, Germany.

Fitmawati F, Hayati I, Sofiyanti N. 2016. Using ITS as a molecular marker for Mangifera species identification in Central Sumatra. Biodiversitas J Biol Divers 17 (2). [Indonesia]

Hapsari L, Azrianingsih R, Arumingtyas EL. 2018. Genetic variability and relationship of banana cultivars (Musa L) from East Java, Indonesia based on the Internal Transcribed Spacer region nrDNA sequences. J Trop Biol Conserv 15:101-120.

Kimura M. 1980. A simple method for estimating evolutionary rates of base substitutions through comparative studies of nucleotide sequences. J Mol Evol 16 (2): 111-120.

Larkin MA, Blackshields G, Brown NP, Chenna R, McGettigan PA, McWilliam H, Thompson JD. 2007. Clustal W and Clustal X version 2.0. Bioinformatics 23 (21): 2947-2948.

Lestari DA, Azrianingsih R, Hendrian H. 2017. Taxonomical position of Annonaceae species from East Java, Indonesia: Collections of Purwodadi Botanic Garden based on morphological character. Biodiversitas 18 (3): 1067-1076. [Indonesia]

Librado P, Rozas J. 2009. DnaSP v5: a software for comprehensive analysis of DNA polymorphism data. Bioinformatics 25 (11): 14511452 .

Nei M, Kumar S. 2000. Molecular Evolution and Phylogenetics. Oxford University Press, USA. 
Nurdjannah N, Bermawie N. 2012. Cloves. In: Handbook of herbs and spices. Woodhead Publishing, Cambridge, UK

Ochieng JW, Muigai AW, Ude GN. 2007. Phylogenetics in plant biotechnology: principles, obstacles, and opportunities for the resource poor. Afr J Biotechnol 6: 639-649.

Purseglove JW, Brown EG, Green CL, Robbins SRJ. 1981. Tropical Agriculture Series: Spices. Vol. 1. Longman Group Limited, London.

Pool PA, Eden Green SJ, Muhammad MT. 1986. Variation in clove (Syzygium aromaticum) germplasm in the Moluccan islands. Euphytica 35 (1): 149-159.

Ray A. 2015. Ashoka Trust for Research in Ecology and Environment, Royal Enclave, Srirampura, Jakkur Post, Bangalore, India.

Saitou N, Nei M. 1987. The neighbor-joining method: a new method for reconstructing phylogenetic trees. Mol Biol Evol 4 (4): 406-425.

Sohrab SS, Azhar EI, Kamal MA, Bhattacharya PS, Rana D. 2014 Genetic variability of Cotton leaf curl betasatellite in Northern India. Saudi J Biol Sci 21 (6): 626-631.

Swofford DL. 2002. PAUP: phylogenetic analysis using parsimony (and other methods), 4.0 beta. http://paup. csit. fsu. edu/.
The Crop State Statistics of Indonesia. 2015. Clove. Ministry of Agriculture, Jakarta. [Indonesia]

Tresniawati C, Randriani E. 2016. The kinship test of clove accession in Sukapura Experimental Garden. Bull Plasma Nutfah 17 (1): 40-45. [Indonesia]

Van der Merwe MM, Van Wyk AE, Botha AM. 2005. Molecular phylogenetic analysis of Eugenia L. (Myrtaceae), with emphasis on southern African taxa. Plant Syst Evol 251 (1): 21-34.

Verheij E, Snijders CHA. 1999. Syzygium aromaticum (L.) Merrill \& Perry. In: de Guzman CC, Siemonsma JS (eds) Plant Resources of South-East Asia 13: Spices. Prosea, Bogor. [Indonesian]

White TJ, Bruns T, Lee SJWT, Taylor JL. 1990. Amplification and direct sequencing of fungal ribosomal RNA genes for phylogenetics. PCR protocols: a guide to methods and applications 18 (1): 315-322.

Wilson PG, Heslewood MM. 2016. Phylogenetic position of Meteoromyrtus (Myrtaceae). Telopia 19: 45-55.

Yonemori K, Honsho C, Kanzaki S, Eiadthong W, Sugiura A. 2002. Phylogenetic relationships of Mangifera species revealed by ITS sequences of nuclear ribosomal DNA and a possibility of their hybrid origin. Plant Syst Evol 231 (1-4): 59-75. 